\title{
Micro Finance for Poverty Alleviation - Some Reflections by
}

\author{
${ }^{1}$ Mahesh G Deshpande $\&^{2}$ Mrs. Farzana M Pathan
}

\section{Introduction and the conceptual parameters.}

The subject of providing credit to support people in rural areas has been explored extensively from time to time in India. The Indian Rural credit system, as it has emerged, is a product of both evolution and intervention. The broad objectives of policy intervention have been (a) to institutionalize credit (b) to enlarge its coverage and (c) to ensure provision of timely and adequate finance at reasonable rates of interest to as large as segment of the rural population as possible. The institutional innovations have been a continuous process with changes occurring depending on experience

Globally, over a billion poor people are still without access to formal financial services and some 200 million of them live in India. Micro Finance the provision of a wide range of financial services to the poor on a sustainable basis has proved to be immensely valuable. Access to financial services has allowed many families throughout the developing world (and, indeed, in poorer parts of the developed world) to make significant progress in their own efforts to escape poverty.

In the development paradigm micro-finance has evolved as a need based policy and programme to cater to the so far neglected target group (women, poor, rural, deprived etc) its evolution is based on the concern of all developing countries for empowerment of the poor and the alleviation of poverty. Development organizations and policy makers have included access to credit for poor people as a major aspect of many poverty alleviation programmes.
Micro finance programmes have, in the recent past, become one of the more promising ways to use scarce development funds to achieve the objectives of poverty alleviation, further more certain micro finance programmes have gained prominence in the development field and beyond the basic idea of micro finance is simple if poor people are provided access to financial services, including credit they may very well be able to start expand micro enterprise that will allow them to break out of poverty.

Micro credit is provision of thrift, credit and other financial services and products of small amount to the poor in rural semi urban, and urban areas for enabling to raise income levels and improve living standards. Financial services provided by micro financing institutions include savings, credit, insurance, leasing, money transfer, equity transactions etc., with the qualification that (i) the transaction value is small and (ii) the customers are poor.

Micro credit is distinguished from normal credit in relation to size and clientele group. Micro credit is considered as 'walk in' compared to normal credit, which is considered as 'walk out' business for the financial institutions. Unlike normal credit micro credit is limited with collateral substitute and credit plus services. Micro credit thus becomes distinct form other regular credit where not only credit amount is small but clientele is poor but also credit is provided 'collateral substitute'. Micro financing envisaged mobilizing thrift and supplementing it with loan from the financial institution.

\footnotetext{
${ }^{1}$ Is working for KLE Society's College of Business Administration, Hubli as a Lecturer in Financial Management

'Is working for KLE Society's College of Business Administration, Hubli as a Lecturer in General Management
} 


\section{Strengths of Micro- Finance}

There are some unique features of micro credit that has contributed to its distinctive success against not so successful performance of other forms of rural credit delivery systems like co-operatives, RRB's and commercial banks.

In recognition of the potential of micro finance to address the diverse aspects of poverty, the United Nations launched the international year of micro credit 2005. The year, in the words of the UN Secretary General, Ms. Kofi Annan, "Underscores the importance of micro finance as an integral part of our collective effort to meet the millennium development goals. The challenge before us is to address the constraints that exclude people from full participation in the financial sector... Together, we can and must build inclusive financial sectors that help people improve their lives"

What are the strengths of micro finance and how can it contribute for poverty reduction? The following points may throw some light into these contiguous issues.

1. Micro finance provides support to income generation for enterprises operated from low income households. There is extensive evidence that micro finance helps to reduce poverty through increase in income, allowing the poor to build assets and reducing their vulnerability.

2. Micro finance helps in building self-sufficient, subsidy free, locally managed institutions.

3. Micro finance provides service similar to those used traditionally in the rural sector with greater flexibility and on a more sustainable basis.

4. Development of micro finance strengthens not only the rural sector but also the financial system of the country as a whole. Rural areas provide greater scope for profitability for banks and financial institutions through higher deposit mobilization and credit creed off take.

5. In addition to financial inter mediation many micro finance institutions provide social intermediation such as group formation, training in financial literacy and management capabilities.
Micro finance is therefore not just a banking tool but also a development tool.

6. In addition to the benefits to the rural population the financial institutions advancing the credit also enjoy better recovery rates.

7. Micro finance helps for promoting gender equality and empowering women by increasing their contribution to household income, the value of their assets, and control over decisions, that affect their lives for example: The women's empowerment programme in Nepal found that $68 \%$ of its members were making decisions on property, family planning and daughter's education, and also negotiating their children's marriages.

Thus the biggest strength is bringing financial services to poor people and making it financial sustainable the economies of scale effect. In India the National Bank for Agriculture and Rural Development (NABARD) finances more than 500 banks that lend funds to self help groups (SHG). SHGs comprise twenty or fewer members, of whom the majority are women from the poorest sectors. Nearly 1.4 million SHGs comprising approximately 20 million women now borrow from banks, which make the Indian SHG-Bank Linkage model the largest micro finance program in the world. Similar programs are evolving in Africa and Southeast Asia with the assistance of organizations like Opportunity International, Catholic Relief Services, CARE, APMAS and Oxfam. Also helps in the development of an economy by giving everyday people the chance to establish a sustainable means of income. Eventual increases in disposable income will lead to economic development and growth.

Micro finance is potent method for rural credit delivery with tremendous potential for serving the rural masses. 


\section{Institutional structure of Micro Finance}

There are several micro finance implementing organizations, which provide small loans in India. Some of them have successfully expanded their services to thousands of borrowers. Given the fact that most of these borrowers would not have had access to formal financial institutions, that many of the borrowers utilize the loans to enter and /or expand their informal sector micro enterprises, and that the informal sector continues to be an important source of livelihood for many poor people, these micro finance organizations may very well have had a major impact on improving the living standards of millions of poor persons as well as on promoting economic growth. The term micro finance organizations have been used for all types of implementing organizations facilitating savings and credit and financial activities at individual and / or group level.

Micro finance includes varied types of organizations like NGOs (Non Government Organizations) co-operatives, Banks (Commercial banks, RRBs, other nationalized and Public Sector banks) and NBFCs (Non Banking Financial Companies)

NGOs and voluntary agencies were introduced into the picture since NABARD felt that banks would be unable to efficiently organize such grass- root level groups.

New micro credit companies such as Basix and SEWAaided bank represent a primarily NGO - driven effort to charge market linked, risk adjusted rates of interest on small loans to small borrowers. They also ensure hurdle free access to borrowers and high repayment rates for themselves.

Micro finance interventions can be identified based on their span of activity, source of funds, route through which it reaches the poor or the coverage. How ever, it seems that one of the most common practices and approaches prevalent is providing credit through self-help groups. The approach is to make SHGs the main focal point to rout credit to all the members.
Almost all national funding organizations (NABARD, RMK) as well as other Government schemes advocate forming of self help groups and thus providing or linkage with credit. However, many organizations providing individual finance directly also exist. It has been explained in the following chart.

\section{Micro finance interventions through different organizations.}

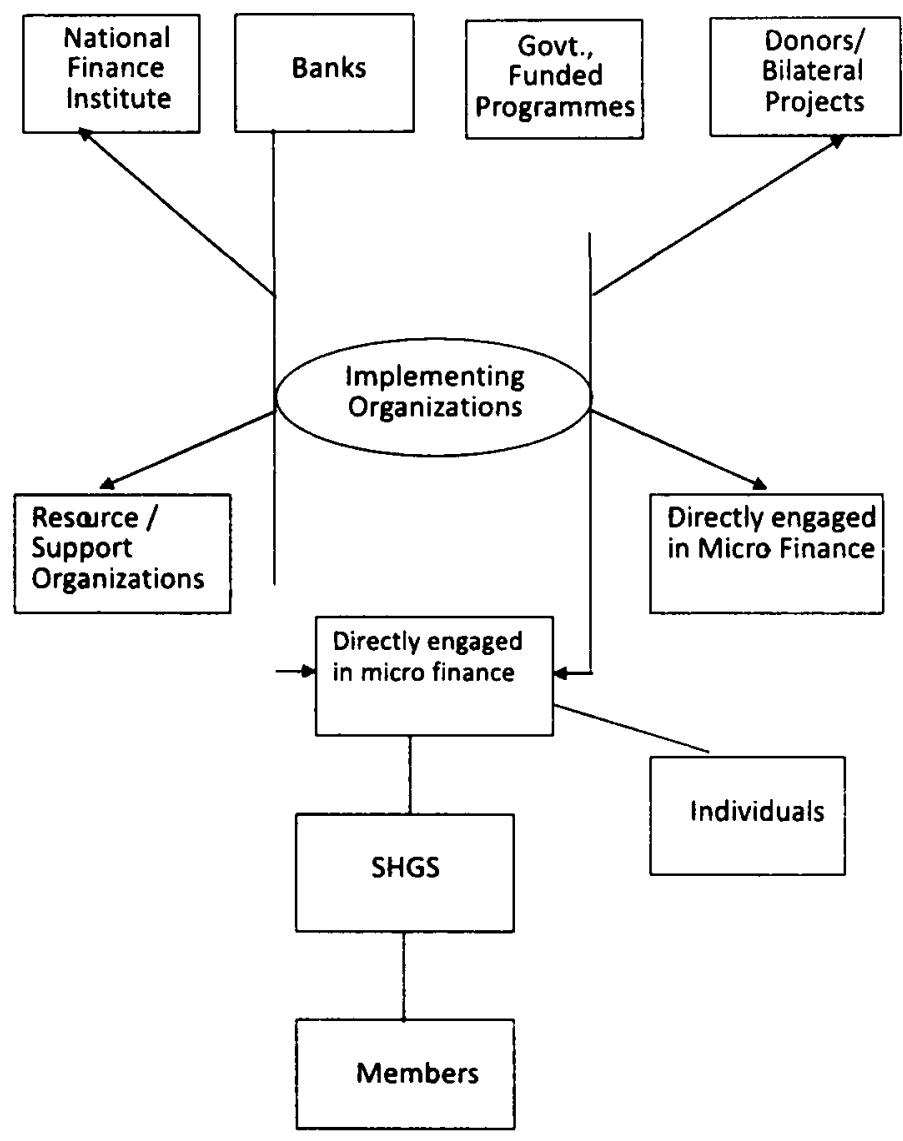

The preparation of this resource directory covered about 450 organizations involved in micro finance activities in 11 states of India. These organizations are classified in the following categories to indicate the functional aspects covered by them within the micro finance framework. The aim, however, is not to "typecast" an organization, as these have many other activities within their scope like,

I. Organizations implementing micro finance activities.

II. Resource organizations / support agencies.

III.Formal financial institutions-Banks and development organizations like NABARD, SIDBI, Association of MFOs etc. 
These organizations have developed guidelines and training materials to help MFOs implement micro-creditactivities covered under their purview.

\section{Limitations and Areas of Concerns of Micro finance}

Certain aspects of micro - finance have been causing concern. A few of them are indicated below.

1. The major problem of micro finance relates to the absence of partner NGOs. The growth of the linkage programme is dependent upon the initiatives and efforts of the partners. Non-availability of NGOs in different parts of the country has come in the way of the progress of the programme.

2. NGOs need to have properly-trained work force to take up group related savings and credit management activities on large scale. In the absence of any organized training system for the field staff of NGOs in savings and credit management of such training other experienced NGOs may have to fill the gap despite their limited resources.

3. Another area of concern of micro finance relates to the sensitization of bank staff. Rapid expansion in the micro finance area requires the bank staff to be sensitized about the needs and specific nature of these customers as against the traditional methods of banking specific attention has to be paid to regional potentials, availability of experienced NGOs, periodic changes at field level etc.

There is lack of research and literature on the actual effectiveness of micro finance as a tool for economic growth. Some argue that there's too much focus on micro finance which will motivate less spending in other helping assistance as public health, welfare and education.

Some doubt micro finance really has that impact on poverty, as the practioners would submit. Other describes micro crediting as a privatization of public safety net programs. There's also some micros finance institutions charging excessive interest rates.
Lastly Studies in the field of micro credit programs have found that women often act as collection agents for their husbands and sons, such that the men spend the money themselves while women are saddled with the credit risk. Some borrowers have become dependent on loans for household expenditures rather than capital investments.

\section{Micro - Finance and the SHGs}

Micro finance activity is the result of NABARD's work that started in 1997 through a pilot project for promoting 500 self- helps groups. With over 11 million poor households accessing banking services including micro credit through their 7, 00,000 self Help Groups (SHGs). The SHG-Bank linkage programme led by NABARD in India is now the largest and the fastest growing micro finance programme of the world in terms of its out reach. Today over 2800 NGOs and 30,000 branches of 500 banks are associated with the programme making it most cost effective micro finance initiative as well due to the economics of scale involved.

\section{Challenges in the Indian context}

Micro finance is a means or an instrument for development not an end in itself. There is need for assessing the extent to which India has been able to achieve the goal of poverty eradication and fulfill its role as a means for development. There is a regulatory frame work within which increasing amount of savings mobilization by micro finance institutions has to take place. In the absence of the same unscrupulous elements may enter the sector and exploit the hard earned savings of the poor.

Micro finance institutions charge comparatively higher interest rate ( 12 to 36 percent per annum). This is again a contentious issue. The high interest rate collected by the institutions from their poor clients is perceived as exploitative. The rate of interest needs to be reduced. 
Another constraint or challenge relates to the capacity of Micro finance institutions to mobilize staff and the availability of capital funds.

Millions of people in India in the low-income groups remain unable to access formal financial services. A very conservative estimate suggests that at most just 20 percent of all low-income people have access to financial services from formal financial institutions, micro finance institutions and other such stakeholders.

"Micro finance institutions" demand for credit is estimated at Rs. 2,00,000 Crores. Against this a meagre Rs. 7000 Crores is recorded as flowing through the channel of banks. We can achieve the goal of poverty reduction if we are able to make the adequate, institutional, financial and policy preparations for it. An important part of this preparation is to make micro credit available to the bottom half o the world's population. One has to be careful in using micro finance as a tool to alleviate poverty. Invariably such projects do no deliver the desired outcome of poverty alleviation because of lack of demand for the goods and services produced by the informal sector / micro enterprises in a stagnant rural sector.

\section{Conclusions}

Micro finance can change the lives of the poor. There may not be a quantum jump in the income but it is possible still to ensure reasonable rise the income of the poor. Micro finance is not yet at the center stage of the Indian financial sector. The knowledge, capital and technology to address these challenges however now exist in India, although they are not yet fully aligned with a more enabling environment and surge in economic growth. The next few years promise to be exciting for the delivery of financial services to poor people in India.

\section{REFERENCES}

1. Rajaram Dasgupta - Micro finance in India - empirical evidence. Alternative models and policy, imperatives economic and political weekly - March-2005.

2. Atulya Venkatraman - Rural Banking - A feasible alternative -website- http // www.projectshub.com/projects/30017/30017,htm.

3. Dr. K Srinivas Rao - Micro Finance - A tool for poverty alleviation and women empowerment.

4. Banking and Finance - January-2007

5. K. Kalpana - Micro Finance wins Nobel - A stock taking-Economic and political weekly, Dec-2006 PP 10-13.

6. Y.S.P Thorat and Graham A. N. Wright - Micro Finance : Banking for the poor, not poor banking. 